\title{
Glycosylated LDL に関する研究*
}

早川道彦** 葛谷文男**

\section{I. 緒言}

生体内で非酵素的にグルコースと結合し安定な 物質となる蛋白として最初にあげられたものはい わゆるグリコヘモグロビンであるが1)，最近にな り各種の蛋白とグルコースとの間においても同様 の非酵素的な反応の起こり得ることが報告されて いる2). グリコヘモグロビンの量は糖尿病患者の 高血糖の程度によって増加することが知られてい るが，これら非酵素的反応を受けた蛋白も同様 に増加すると思われる.グリコへモグロビン, glycosylated albumin 等の測定による診断的価值 とは別に，種々の蛋白質とグルコースとの反応生 成物が糖尿病患者を主体とした長期の合併症の形 成にいかなる関与をしているかについては非常に 興味が持たれる点である. LDL に関してもグル コースと非酵素的反応をひきおこす結果, glycosylated LDL の生成されることが報告されている3 LDL は特に糖尿病患者において動脈硬化症発症 にきわめて重要な役割を演じており，その変性 LDL である glycosylated LDL が病態形成にどの ような影響を及ぼしているかについては詳しくは 解明されていない，最近われわれはこの glycosylated LDL の各種病態における役割を解明する ために簡便な測定法を開発するとともに糖尿病に おける動脈硬化症について若干の興味ある知見を 得たので報告する.

\section{II. 方 法}

血清中の Glycosylated $\beta$-Lipo 蛋白は，次の方 法によって行った.

$400 \mu l$ の血清をアガロースに結合した boronate

* 1985 年 1 月, 日本動脈硬化学会 炤和59年度冬季大 会において発表

** 名古屋大学医学部老年科
を affinity medium とする column に注入したあ と，グリシンー塩化マグネシウム，アジ化ナトリ ウムを含有する溶出液 $2.0 \mathrm{ml}$ によって溶出した 分画を non Glycosylated $\beta$-Lipo 蛋白，またソル ビトールを含有する溶出液 $2.0 \mathrm{~m} l$ によって溶出 液した分画を Glycosylated $\beta$-Lipo 蛋白とし各溶 出した分画中に含まれる $\beta$-Lipo 蛋白を日本商事, $\mathrm{BL}$ キット $\mathrm{K}$ を用いて測定を行った. 患者血清中 におけるGlycosylated $\beta$-Lipo 蛋白の量は総 $\beta$ Lipo 蛋白 LDL に対する Glycosylated $\beta$-Lipo 蛋 白の比で表した. なおこの方法はすでに Glycosylated 蛋白の測定に応用されている方法である.

対象は本院外来, 入院患者および健康診断受診 者である.

$1 \%$ コレステロール食にて 3 か月間飼育を行 った家鬼より得た血清に $20 \mathrm{mM}$ の glucose を加 え 3 時間 $37^{\circ} \mathrm{C}$ incubation を施し, 高 Glycosylated LDL 血清を作製した.この血清を正常家鬼に 5 $\mathrm{m} l / \mathrm{kg}$ を耳動脈より注入し経時的に本法により Native $\beta$-Lipo 蛋白抒よび Glycosylated $\beta$-Lipo 蛋白濃度の測定を行い注入前值に至るまでの半減 期を測定した。

\section{III. 結 果}

健康者 137 名および糖尿病患者 28 名における Glycosylated $\beta$-Lipo 蛋白の量はそれぞれ $14.1 \pm$ $3.2,19.6 \pm 5.8 \%$ と糖尿病患者では健康者に比較 して本法による Glycosylated $\beta$-Lipo 蛋白は高值 を示した (Fig. 1). 次に糖尿病患者における本法 による Glycosylated $\beta$-Lipo 蛋白の值と他の糖代 謝異常に打ける生化学值の比較を行ったところ次 の結果が得られた.グリコヘモグロビンと本法に よる Glycosylated $\beta$-Lipo 蛋白は Fig. 2 に示すご とく $\mathrm{R}=0.897$, 危険率 $0.1 \%$ 以下で正の相関を示 した. また総コレステロールと Glycosylated $\beta$ - 
Lipo 蛋白は同様に $\mathrm{R}=0.845$, 危険率 $0.1 \%$ 以下と 相関が得られた (Fig. 3).

$1 \%$ コレステロール食にて 3 か月間飼育を行っ た家鬼より得た血清に $20 \mathrm{mM}$ の glucose を加え 3 時間 $37^{\circ} \mathrm{C}$ incubation を施し, 高 Glycosylated

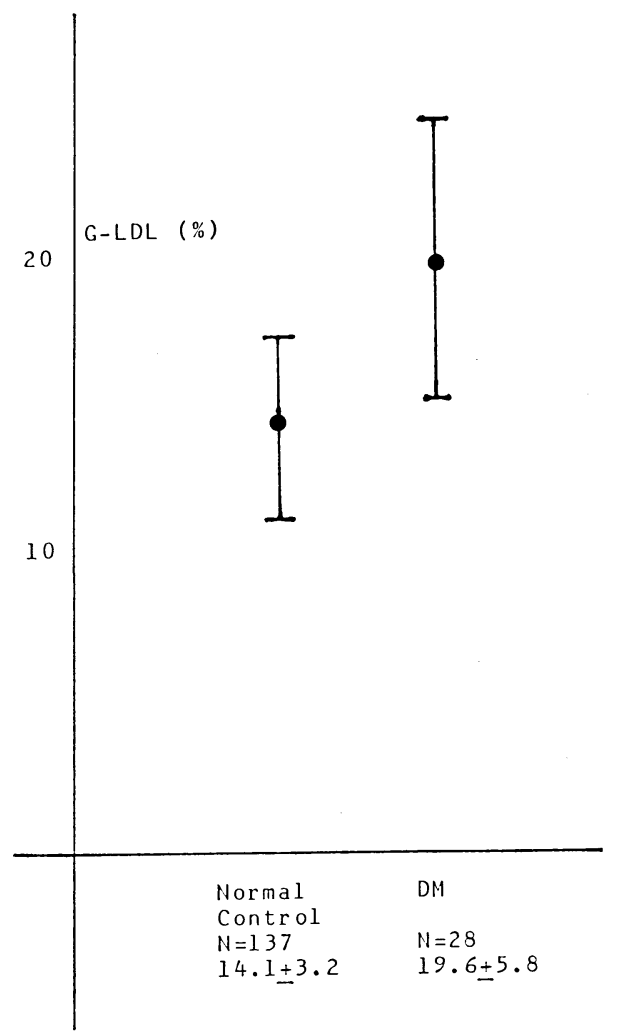

Fig. 1

LIMEAR REGRESSION STUDY

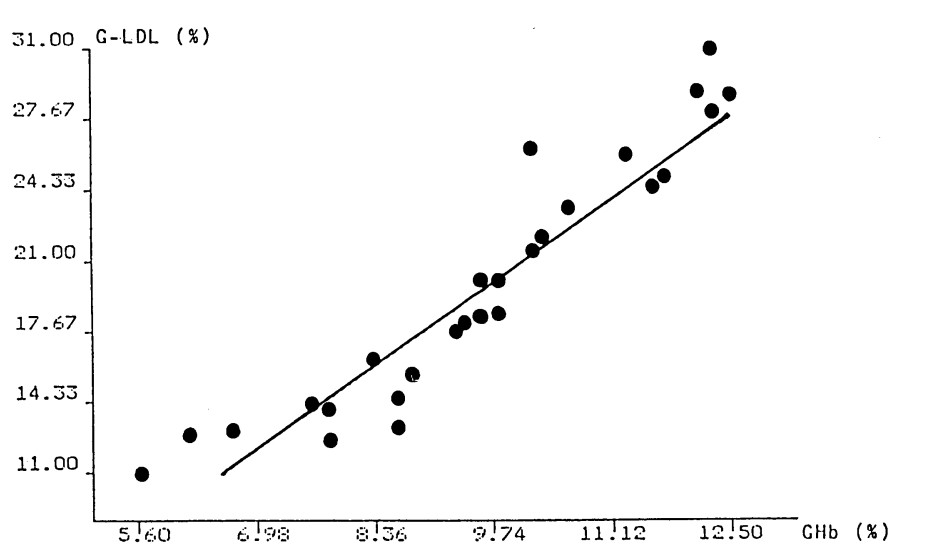

Fig. 2
$R=0.007 \quad P<0.001$
$\beta$-Lipo 蛋白血清を作製した. この血清を正常家 鬼に $5 \mathrm{ml} / \mathrm{kg}$ を耳動脈より注入し経時的に本法に より Native $\beta$-Lipo 蛋白および Glycosylated $\beta$ Lipo 蛋白の濃度の測定を行い注入前值に至るま での半減期を測定したところ Fig. 4 に示すごと < Glycosylated $\beta$-Lipo蛋白は Native $\beta$-Lipo 蛋白 に比較し血中クリアランスは遅延することが認め られた。

\section{IV. 考 察}

LDL の動脈硬化形成における役割が重要な点 であることは述べるまでもない．特に糖尿病患者 における高コレステロール血症が血管障害発症に 重要な因子となっており長期にわたる管理が必要 とされている．糖尿病管理に通常グリコへモグロ ビン，すなわちへモグロビンとグルコースとの非 酵素的結合をしたものが指標とされ, 最近では Glycosylated Alubumin, Glycosylated Protein の 代謝および測定法にたいする研究が重要視される に至った. 最初に述べたごとく同様の反応によっ て生じた変性 $\beta$-Lipo 蛋白の一つである Glycosylated $\beta$-Lipo 蛋白に関しても，動脈硬化症発症 における病態生化学的意義についての研究がなさ れるようになってきている。しかしその測定には 分離を初めとして種々の困難な点が存在し, 容易 に測定を行う方法の開発が望まれている。そこで われわれは Glycosylated $\beta$-Lipo 蛋白を簡易に測定 する方法を見いだした。この方法は Glycosylated 


\section{Glycosylated LDL に関する研究}

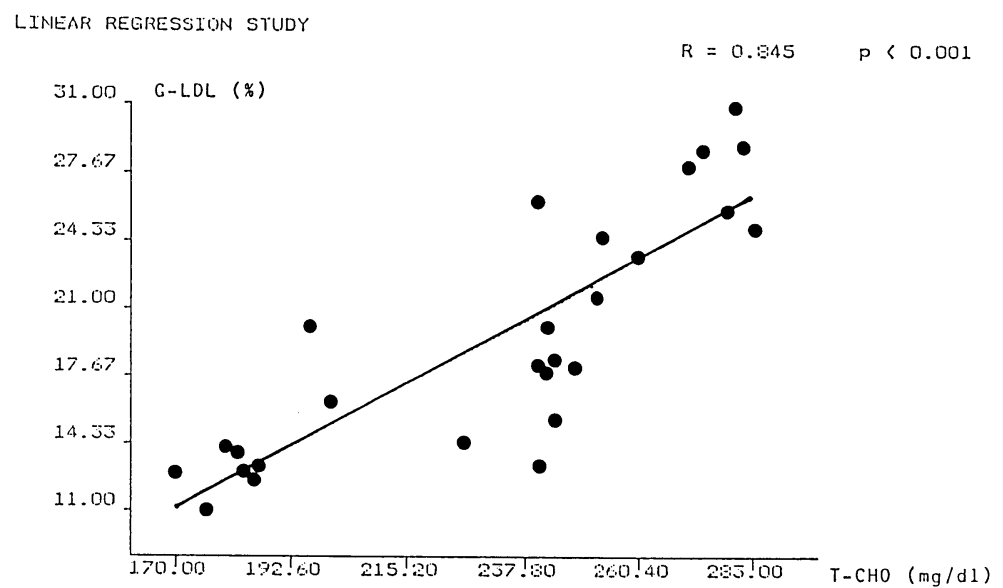

Fig. 3

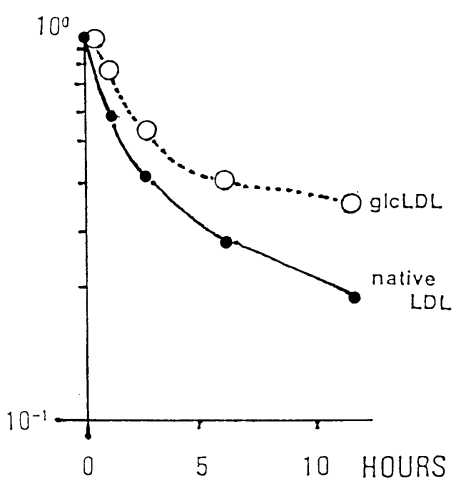

Fig. 4

Protein をアガロースゲルによる affinity column により分離するものであり操作方法の容易さ，測 定時間の短さに非常な利点がある. しかし温度に 影響されやすい点があり注意が必要である．特に 従来より行われている超遠心法は，その分離に時 間がかかりすぎ測定中に変性をきたす可能性が示 されている，本法によって得た糖尿病患者に招け る Glycosylated $\beta$-Lipo 蛋白の值は血糖值に応じ て増加することが認められ, その代表である $\mathrm{GHb}$ と良い相関が得られた。 また家鬼における Glycosylated $\beta$-Lipo 蛋白が $\beta$-Lipo 蛋白に比較して半 減期の低下を示すことおよび糖尿病患者における コレステロール值が Glycosylated $\beta$-Lipo 蛋白と きわめて良い相関を示すことは従来より報告され ている変成 LDL と正常 LDL のリ七プターに おける結合の差などを考えると出，本法による
Glycosylated $\beta$-Lipo 蛋白の測定がこれら代謝異 常における動脈硬化症発症の機構の解明および発 症予防に有益なことと思われたので報告した。

\section{V. 結 論}

われわれは Glycosylated $\beta$-Lipo 蛋白を容易に 測定できる方法を考案し糖尿病患者において本法 により測定を行った。その結果本法による Glycosylated $\beta$-Lipo 蛋白の測定は, 他の耐糖能異常を あらわす指標と良い相関を得，また家兔における 実験にて半減期の延長を認めた.

これらは糖尿病患者における動脈硬化症の発症 の解明にきわめて重要な意義を持つと思われたの で報告した.

\section{文 献}

1) Higgins, P. J., Garlic, R. L. and Bunn, H. F.: Glycosylated hemoglobin in human and animal red cells. Diabetes, 31: 743-748 (1982).

2) Kennedy, L., Mehl, T. D., Elder, E., Varghese, M. Merimee, T. J.: Non enzymatic glycosylation of serum and plasma proteins. Diabetes, 31: $52-56$ (1982).

3) Schleicher, E., Deufel, T. and Wieland, O. H.: Non enzymatic glycosylation of human serum lipoproteins. F.E.B.S. LETTERS, 129: 1-5 (1981).

4) Sasaki, J. and Cottam, G. L.: Glycosylation of LDL decreases its ability to interact with high affinity receptors of human fibroblast in vitro and decreases its clearance from rabbit plasma in vivo. B.B.A., 713: 199-207 (1982). 


\title{
Summary
}

\section{Measurement and Metabolism of Nonenzymatically Glycosylated LDL}

\author{
Michihiko Hayakawa and Fumio Kuzuya
}

Department of Geriatrics, Nagoya University, School of Medicine

It is well known that atherosclerosis is accelerated in patient with diabetes mellitus (DM). If some plasma proteins undergo non enzymatic glycosylation in DM and certain chemical modifications of LDL give the alterations in their interactions with certain cells, it is easy to understand that atherosclerosis may be relevant in DM. We found new simple method for analysis of plasma Glycosylated beta-lipoprotein (G-b-lipo) by affinity column chromatography and measured the plasma G-b-lipo in DM or non diabetic subjects. The Value of plasma G-b-lipo was higher in DM than non diabetic subjects. The higher levels of plasma G-b-lipo in DM appear to reflect hyperglycemia for the past several days and correlate with other established parameters of hyperglycemia such as glycosylated hemoglobin.

Also, we observed that the clearance rate of G-b-lipo prepared from rabbit plasma was lower as compared to native b-lipo in identical rabbit.

These results gave us special interests with regard to the role which G-b-lipo may play on the hyperlipidemia and angiopathies in DM.

Key words: Glycosylated beta lipoprotein, diabetes mellitus, hyper lipidemia, angiopathies. 